\title{
Modelling potential distribution of the endemic ringtail (Bassariscus astutus saxicola) on an island of the Gulf of California
}

\author{
Arnaud, Gustavo ${ }^{1}$; Sandoval, Sarahi ${ }^{2 *}$, Escobar-Flores, Jonathan G. ${ }^{3}$, Sansores-Sánchez, Rigel ${ }^{1}$ \\ 1 Centro de Investigaciones Biológicas del Noroeste, S.C., La Paz. B.C.S, México. \\ ${ }^{2}$ CONACyT - Instituto Politécnico Nacional, CIIDIR Unidad Durango, Dgo., México. \\ ${ }^{3}$ Instituto Politécnico Nacional, CIIDIR Unidad Durango, Dgo., México. \\ *Corresponding author: sarahisandovale@gmail.com
}

Citation: Arnaud, Gustavo, Sandoval, Sarahi, Escobar-Flores, Jonathan G., \& Sansores-Sánchez, Rigel. (2021). Modelling potential distribution of the endemic ringtail (Bassariscus astutus saxicola) on an island of the Gulf of California. Agro Productividad, 14(\#). https://doi.org/10.32854/agrop.v14i6.2042

Editor in Chief: Dr. Jorge Cadena Iñiguez

Estimated publication date: July 2021

This work is licensed under a Creative Commons Attribution-NonCommercial 4.0 International license

\begin{abstract}
Objetivo: Analizar la topografía de una isla del Golfo de California, México, mediante modelos digitales de elevación (DEM) de 30 m de resolución espacial para generar el primer modelo de distribución potencial para el carnívoro endémico Bassariscus astutus saxicola.

Diseño/Metodología/Enfoque: Se empleó el software Maxent para modelar la distribución potencial del babisuri en la Isla Espíritu Santo. Los muestreos se realizaron en 2015-2016 en ocho bahías en el oeste de la isla en donde se capturaron $\mathrm{n}=74$ individuos.

Resultados: Las variables con mayores aportes a los modelos fueron elevación, (71.6\%); índice de carga de calor (15\%) y rugosidad del (11.8\%). El modelo predijo ( $p>0.5)$ probabilidades de presencia del carnívoro en 3,018 hectáreas de la isla. SE obtuvo un valor alto de AUC (0.928), lo que indica que el modelo es exacto, y posteriormente se confirmó con un valor de $\mathrm{pAUC}=1.917$.

Limitaciones/Implicaciones del estudio: El hábitat del B. astutus saxicola era poco conocido principalmente porque es una especie endémica, y no existen publicaciones sobre su distribución dentro de la isla.

Conclusiones: Este modelo muestra que las variables topográficas son útiles para explicar la distribución potencial del B. astutus saxicola, presumiblemente porque la topografía se relaciona con sitios que ofrecen refugio termal, alimento suficiente y cobertura de escape a depredadores, entre otras características del hábitat.
\end{abstract}

Keywords: carnívoro endémico; GIS; modelo de distribución, topografía.

\section{INTRODUCTION}

The islands of the Gulf of California are ecosystems with a rich biodiversity and high number of endemic species (CONANP, 2000); however, the resident species are in many cases threatened due to various human activities, including tourism (Sanchez-Pacheco et al., 2000). This is the case of the ringtail (ringtail cat, miner's cat) on an island in the Gulf of California, Mexico (Carnivora: Procyonidae) (ÁlvarezCastañeda, 2000). In the IUCN (International Union for Conservation of Nature) Red List of Threatened Species, the ringtail is listed as Least Concern (LC) because it is common and widely distributed from central USA to Mexico (Barja and List, 2006). In Mexico, the distribution of Bassariscus astutus ranges from the desert region of the Baja California peninsula to Oaxaca. Three islands in the Gulf of California are included in its distribution: Tiburón, Espíritu Santo, and San José (Lawlor, 1983). In Espíritu Santo Island, the endemic ringtail (B. a. saxicola) has crepuscular and nocturnal habits; it is an opportunistic forager, with an omnivorous diet (Rodríguez-Estrella et al., 2000; Harrison, 2012), preferentially consuming arthropods, small mammals, and fruit (Poglayen-Neuwall and Toweill, 1988). It has been assumed that the diet of this species 
may be impacted by the numerous tourists that visit the island year-round (ÁlvarezCastañeda, 2000); however although the ringtail consumes some food of anthropogenic origin, according to a recent study, such foods do not make up a significant percentage of its diet (Sansores-Sánchez, 2016).

In desert environments ringtails occur in habitats often associated with rocky outcroppings, cliffs, or steep slopes where their dens are found (Hall, 1981). These topographic features are not known on Espíritu Santo Island. Although ecological niche models evaluate the niche dynamics of a species and determines the most important environmental predictors that affect its potential distribution (Guisan and Zimmermann, 2000; Pearman et al., 2008), it is possible to increase the reliability of these distribution models if they include topographic variables (slope, elevation, and ruggedness), and heat indexes generated on slopes according to their geographical exposure. In this context, the aims of this study were: 1) to analyze the topography of the island with a digital elevation model (DEM), and 2) to generate the first potential distribution model for an endemic carnivore (B. astutus Saxicola) that exists in the islands of the Gulf of California.

\section{METHODS AND MATERIALS}

Bassariscus a. saxicola was studied in the Espíritu Santo Island Complex (24 24'$24^{\circ} 36^{\prime} \mathrm{N}$; and $110^{\circ} 18^{\prime}-110^{\circ} 27^{\prime} \mathrm{W}$ ) in an area of 10,390 ha. Mountain ranges run eastwest, with a maximum height of $600 \mathrm{~m}$; most of the east coast are cliffs, while the west portion of the island has a dozen bays, inlets, and coves, formed by the gradual slope of the mountains toward the sea (CONANP, 2000). The climate is dry-arid, with temperatures ranging from $11{ }^{\circ} \mathrm{C}$ to $44{ }^{\circ} \mathrm{C}$; the annual average rainfall is $159.5 \mathrm{~mm}$, with rainfall concentrated from July to October. The predominant vegetation is scrub vegetation, and in the bay mangroves (Laguncularia racemosa) predominate (CONANP, 2000; Carreño and Helenes, 2002) (Figure 1).

\section{Capture of ringtail}

The study was conducted in 2015-2016, through four survey trips: two in the dry season (May and July) and two during the rainy season (September and October). Ringtails were trapped in eight glens on the west of the island by means of ten Tomahawk Live Traps (Mod. 207, $81 \times 25 \times 30 \mathrm{~cm}$ ), of which five were placed parallel to the coastline among the vegetation at the entrance to the glen, and five along the bottom of the ravine, $30 \mathrm{~m}$ apart. Fresh sardines were used as bait. Traps were baited before dark (19:00 h) and checked before dawn (4:00 h). Data of the captured animals were recorded, which included sex, physical condition, and morphometric measurements. They were marked with a numbered metal ring at the base of the ear and later released at the same site where they were captured (Figure 2). 


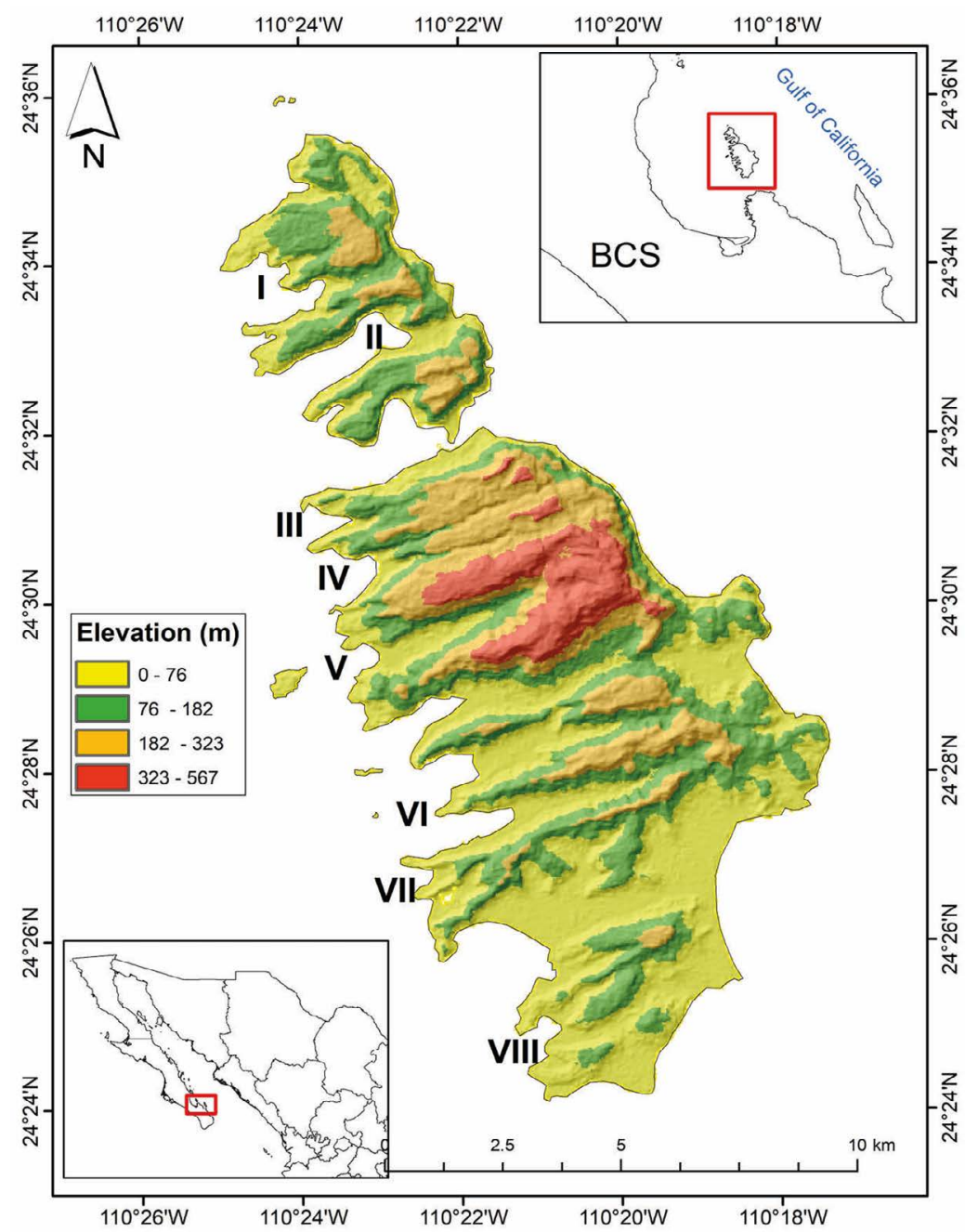

Figure 1. Study area of the endemic ring-tailed cat (B. astutus saxicola) of Espiritu Santo Island, Gulf of California, Baja California Sur (BCS). Ensenada grande Bay (I), El cardonal (II), El Candelero (III), Mesteño (IV), La ballena (V), El corralito (VI), El gallo (VII) and Dispensa Bay (VIII).

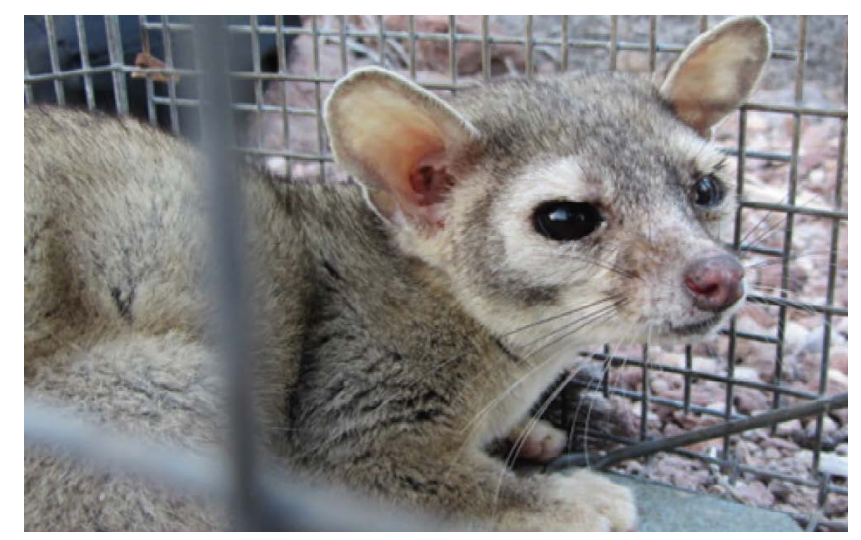

Figure 2. Ringtail Bassariscus a. saxicola from the Espiritu Santo Island. 


\section{Environmental variables}

The literature reported that ringtail inhabits rocky outcroppings, cliffs, or steep slopes (Poglayen-Neuwall and Toweill, 1988). We found four topographic variables to be relevant for this species: a) elevation above sea level (masl), b) slope (0 to 90 $)$, c) terrain ruggedness and d) heat load index (HLI). Terrain ruggedness quantifies the dispersion of the vector orthogonal to the terrain surface; this index is unitless and has values from 0 (flat sites) to 1 (canyons and cliffs) (Sappington et al. 2007). The HLI describes the amount of heat that is generated on a slope and is calculated by rescaling aspect from zero to one, with 0 being the coolest slope (northeast) and 1 being the warmest slope (southwest) (McCune and Keon, 2002). All these features were estimated through the spatial analysis tools available in ArcGIS 10.7.1, using terrain analysis tools and digital elevation models (DEM) from the Advanced Spaceborne Thermal Emission and Reflection Radiometer (ASTER) at $30 \mathrm{~m}$ spatial resolution. It was downloaded from the US. Geological Survey (USGS) Global Visualization Viewer at http://glovis.usgs.gov/.

\section{Maxent modelling}

The maximum entropy model algorithm (Maxent, V. 3.4.1) was used to determine the geographic potential distribution of ringtails (Phillips et al., 2006). The Maxent method for species distribution modelling uses presence and background data (hence absence data is not necessary) for predicting species distribution by a logistic regression model. We used the four topographic features and the presence records for the model. The default Maxent setting sampled 10,000 background points from the study area and set the minimum number of iterations to 500 and the regularization multiplier to one.

\section{Model Accuracy Estimation}

The area under the receiver operating characteristic curve (ROC) was used to evaluate the discriminative ability of the Maxent models. The Area under the curve (AUC) values greater than 0.70 were considered to distinguish between presence and potentially unsampled locations (Elith, 2000). Also, Maxent estimated the environmental variable contributions to the models with permutation importance (values from 0 to 100\%). The use of AUC in predictive accuracy of presence data model has been criticized (Lobo et al., 2008); therefore, analysis of model performance using a partial-AUC procedure was carried out (Barve, 2011). This analysis was done using the NicheToolBox tool (available at: https://shiny.conabio.gob.mx). To validate the model precision, we used the following parameters: omission rate 0.05 , random points percentage $50 \%$, number of bootstrap iterations $=500$ (Eq. 1). The equation used by the NicheToolBox tool is (Eq. 1), where random AUC = Random value of AUC generated from bootstrapping and perfect $\mathrm{AUC}=\mathrm{AUC}$ value calculated for each iteration of the model with Maxent.

$$
p A U C s=\frac{1}{2}\left(\frac{p A U C-\text { random } A U C}{\text { perfect } A U C-\text { random } A U C}+1\right)
$$




\section{Results and Discussion}

A total of $n=74$ ringtail specimens were captured. The sex ratio was $0.85(n=34$ females, $n=40$ males), of which 34 were adults and six males were juveniles. Most of the ringtail captures ( $n=22$ ) occurred in the Ballena Bay. In this Bay, forty three individuals were captured in the dry and 31 in the rainy season. We captured most ringtails in the northern portion of the Island. All ringtail captures were conducted at elevations of 12-60 meters, slopes $0^{\circ}-30^{\circ}$, coolest slopes, and ruggedness 0-0.02 (Figures 3, 4).

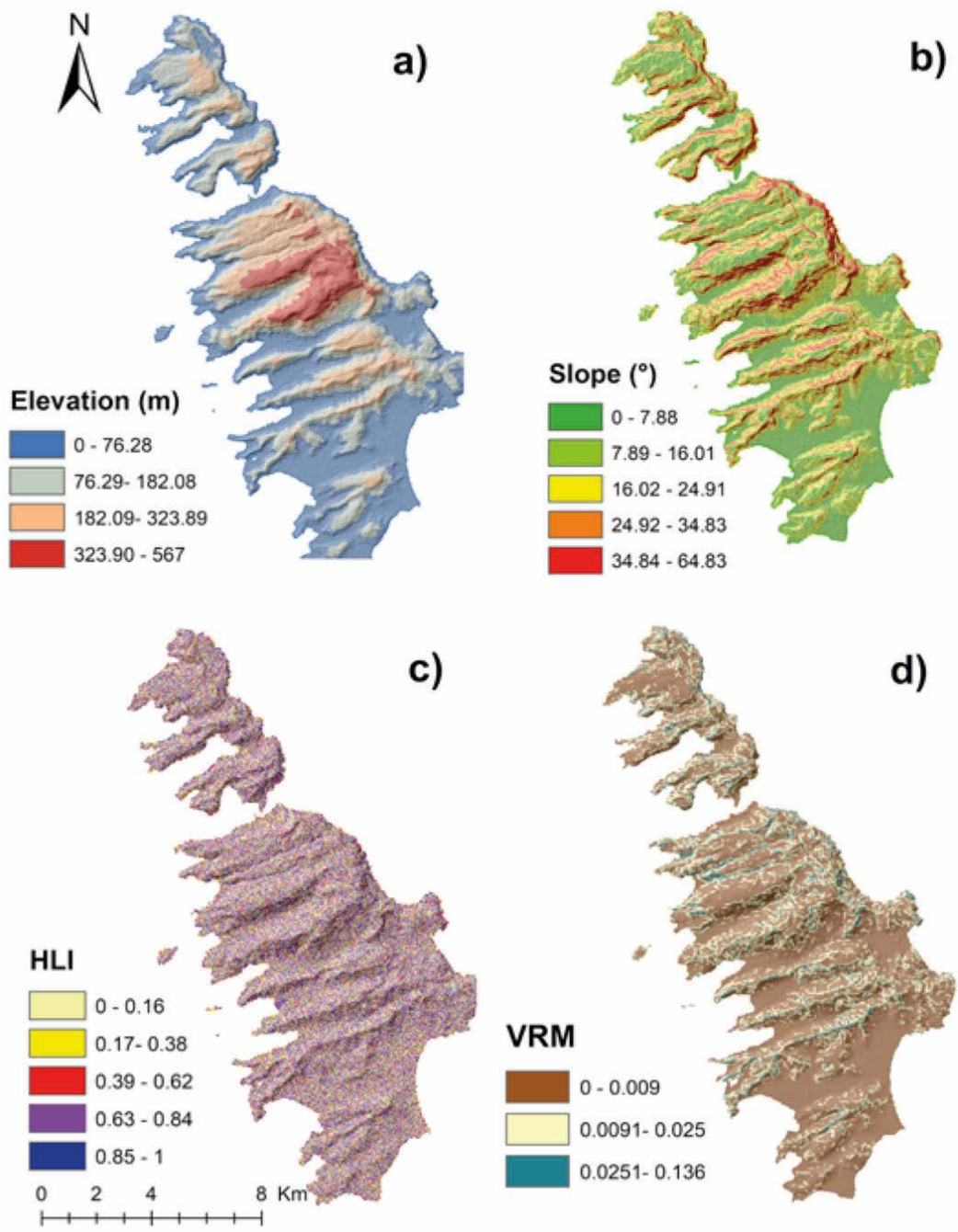

Figure 3. Topographic characteristics in Espíritu Santo Island Complex Baja California Sur, Mexico. a) elevation, b) slope, c) HLI, d) VRM. 


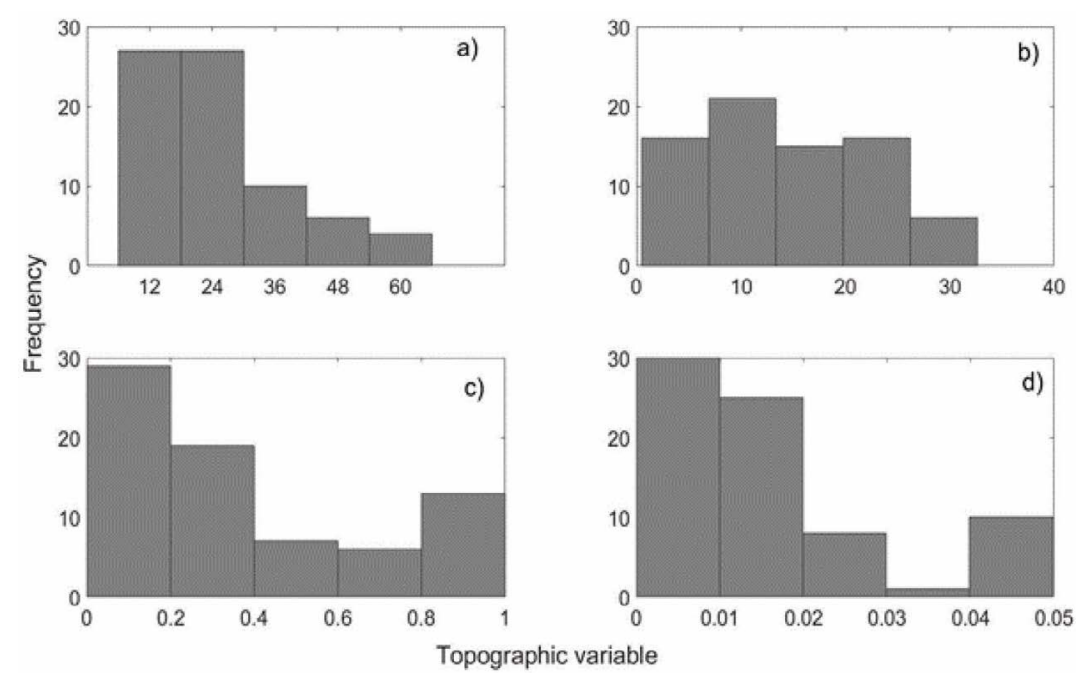

Figure 4. Topographic variables of ringtail captures. a) elevation, b) slope, c) HLI, and d) VRM.

The modeling showed that the potential distribution of the ringtail at a $>0.5$ probability was of 3,018 ha. The AUC was 0.928 , which indicates that the model was able to distinguish between presence and potential presence. The variables that most contributed to determine the presence of ringtail were elevation with 71.6\%, HLI with $15 \%$ and VRM $11.8 \%$. It can be observed (Figure 5) that the areas of potential distribution were canyons containing west aspects. The ROC value was 1.917, this indicates that the model made a good prediction of the potential distribution of ringtails in the Espiritu Santo Island (Figure 6).
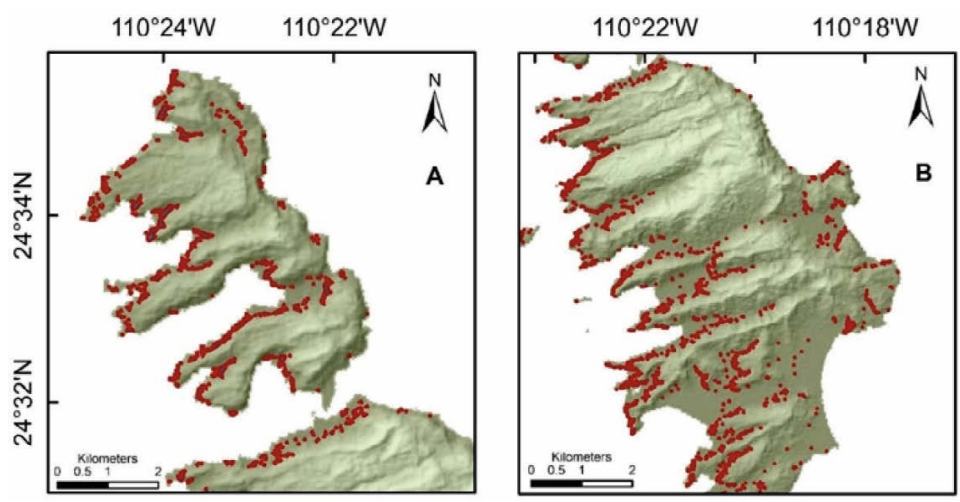

Figure 5. Maps of potential distribution with probabilities $>0.5$ (red polygons) of $B$. a. saxicola in the Espíritu Santo Island, Baja California Sur. Northern (A) and southern mountains (B). 


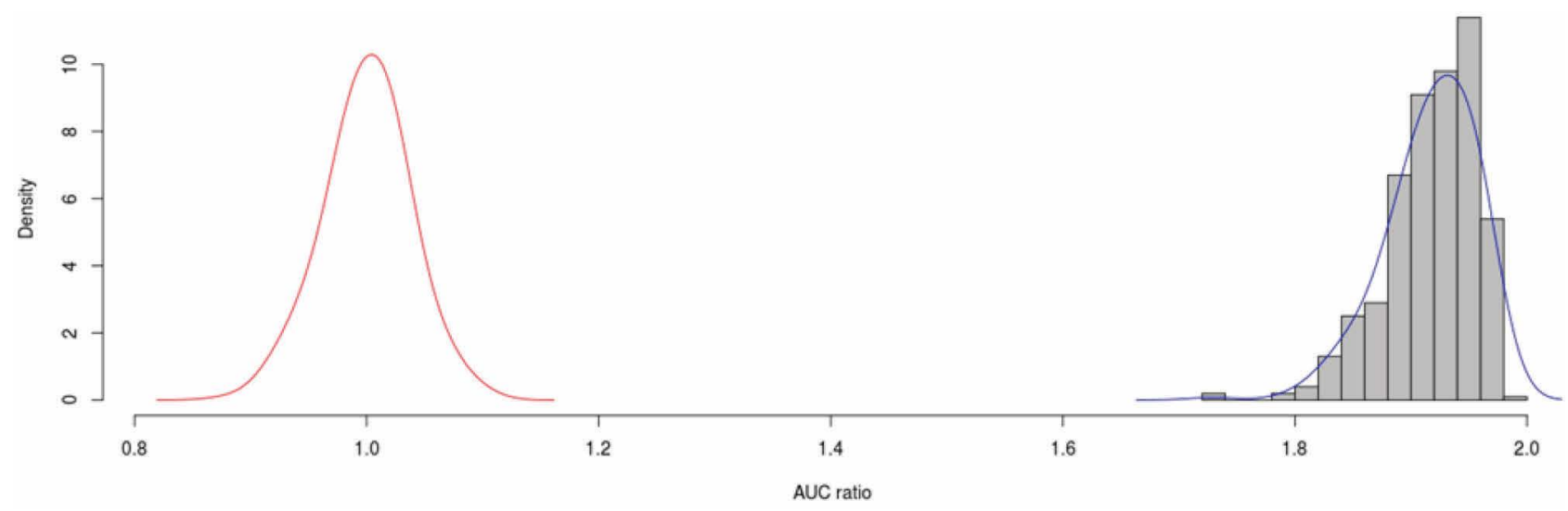

Figure 6. Partial AUC Distribution. The red line indicates the values obtained for the random AUCs derived from bootstrapping. The gray bars are the AUC derived from the Maxent model.

The presence of steep slopes, rocky sites, permanent water and vegetation cover are key elements of the ringtail habitat (Gehrt, 2003). On Espíritu Santo Island, elevation, coolest slope, and ruggedness (VRM) were the variables that most contributed in prediction model of ringtail habitat preferences. Ruggedness is a variable describing the heterogeneity of the elevation, slope, and aspect of a mountain (Sappington et al., 2007). We captured the ringtails in sites with the highest values of ruggedness on the island; and we obtained a high AUC value (0.928), which indicates that the model was accurate; we also confirmed it with a value of $\mathrm{pAUC}=1.917$. Similar results were reported by Ray et al. (2018), when they calculated pAUC of the distribution model made with Maxent using only presence data.

This model shows that topographic variables are useful to explain the potential distribution of the ringtail, mainly because the topography is related to sites that can offer thermal refuge, sufficient food, and escape cover from predators, among other features. There are several studies that also show that topography is a key feature for determining the potential habitat of this species (Moreno et al., 2011; Bradie and Leung, 2017).

The distribution model that we obtained for this carnivore was expected to have a higher probability at higher elevations $(>500 \mathrm{~m}$ ) and isolated canyons. However, the model predicts that the ringtails are distributed mainly in the western bays. This distribution match (overlap) with sites visited by tourists, and according to by SansoresSánchez (2016), at these sites the ringtails feed mainly on insects and Ficus palmeri fruits. Apparently, at these sites, tourism does not have an influence on the ringtails' diet and its presence.

P permanent water is a factor that influences the presence of ringtails (Chevalier, 1984), but on the Espíritu Santo Island fresh water is not available, suggesting that ringtail obtains water from metabolic processes. In the Espíritu Santo Island, it is possible that ringtail fulfill its water requirements through the consumption of fruits of Ficus palmeri and cacti plants (Stenocereus gummosus, Ferocactus sp, Mamillaria sp, and Echinocereus sp) (Sansores-Sánchez, 2016). 
According to home range studies, ringtail requires about 40 ha per individual (Toweill and Teer, 1980). Espíritu Santo Island has an area of 10,390 ha. In this study, we determine that the potential distribution of ringtail covers an area of 3,018 ha, suggesting that the size of population in the island (considering 40 ha of home range per individual) could be of 75 individuals. This information needs to be validated by conducting capture studies at random sites within the potential distribution map defined for the Espíritu Santo Island.

This study was conducted in one of the three islands of the Gulf of California. To design better conservation strategies for the ringtail, we recommend to define the potential distribution of ringtail for the two other islands (San José and Tiburón islands) of the Gulf of California. We still have the challenge to complement ringtail surveys on the east side of the Espíritu Santo lsland where we could not conduct surveys at inaccessible areas due to sea waves.

\section{CONCLUSIONS}

The topographic variables are useful to determine the potential distribution of the ringtail since they offer thermal refuge, sufficient food, and escape cover from predators, among other habitat features.

\section{ACKNOWLEDGEMENTS}

Israel Guerrero and Abelino Cota (Animal Ecology Laboratory, CIBNOR) provided priceless support conducting fieldwork.

\section{REFERENCES}

Álvarez-Castañeda, S. T. (2000). Familia Procyonidae. In Álvarez-Castañeda, S. T., Patton, J. L. (Ed.). Mamíferos del noroeste de México. Vol. II. Centro de Investigaciones Biológicas del Noroeste 717-730 pp. Mexico.

Barja, I., \& List, R. (2006). Faecal marking behaviour in ringtails (Bassariscus astutus) during the non-breeding period: Spatial characteristics of latrines and single faeces. Chemoecology, 16, 219-222. https://doi.org/10.1007/s00049-006-0352-x

Barve, N., Barve, V., Jiménez-Valverde, A., Lira-Noriega, A., Maher, S.P., Peterson, A.T., Soberón, J., Villalobos, F. (2011). The crucial role of the accessible area in ecological niche modeling and species distribution modeling. Ecological Modelling, 157: 101-118. https://doi.org/10.1016/j.ecolmodel.2011.02.011

Bradie, J., \& Leung, B. (2017). A quantitative synthesis of the importance of variables used in MaxEnt species distribution models. Journal of Biogeography, 44(6), 1344-1361. https://doi.org/10.1111/jbi.12894

Carreño, A. L., \& Helenes, J. (2002). Geology and ages of the islands. In Case, T. J., Cody, M. L., Ezcurra, E. (Ed.). A new island biogeography of Sea of Cortes. Oxford University Press. EE UU.

Chevalier, C. D. (1984). Water requirements of free-ranging and captive ringtail cats (Bassariscus astutus) in the Sonoran Desert. Master's thesis, Tempe, EEUU: Arizona State University.

CONANP. (2000). Programa de Manejo del Complejo Insular Espíritu Santo Baja California Sur. SEMARNAT. México.

Elith, J. (2000). Quantitative methods for modeling species habitat: comparative performance and an application to Australian plants. In Ferson S., Burgman M. (Ed.). Quantitative methods for conservation biology, Springer, New York.

Gehrt, S. D. (2003). Ringtail. In Feldhamer GA, Thompson BC, Chapman JA (Ed.). Wild Mammals of North America: Biology, Management and Conservation. Second edition. The Johns Hopkings University Press. Baltimore. 
Guisan, A., \& Zimmermann, N. E. (2000). Predictive habitat distribution models in ecology. Ecological Modelling, 135(2-3),147186. https://doi.org/10.1016/S0304-3800(00)00354-9

Hall, E. R. (1981). The mammals of North America, 2nd ed. John Wiley, New York, pp. 90.

Harrison, R. L. (2012). Ringtail (Bassariscus astutus) ecology and behavior in Central New Mexico, USA. Western North American Naturalist, 72(4), 495-506. https://doi.org/10.3398/064.072.0407

Lawlor, T. (1983). The Mammals. In T.J. Cade \& M.L. Cody (Ed.). Island Biogeography in the Sea of Cortéz, 508 pp. University of California Press, Berkeley, California, USA.

Lobo, J.M., Jiménez-Valverde, A., Real, R. (2008) AUC: a mis-leading measure of the performance of predictive distribution models. Global Ecology and Biogeography, 17, 145-151 https://doi.org/10.1111/j.1466-8238.2007.00358.x

McCune, B., \& Keon, D. (2002). Equations for potential annual direct incident radiation and heat load. Journal of Vegetation Science, 13(4), 603-606. https://doi.org/10.1111/j.1654-1103.2002.tb02087.x

Moreno, R., Zamora, R., Molina, J. R., Vasquez, A., \& Herrera, M.Á. (2011). Predictive modeling of microhabitats for endemic birds in South Chilean temperate forests using Maximum entropy (Maxent). Ecological Informatics, 6(6), 364-370. https:// doi.org/10.1016/j.ecoinf.2011.07.003

Pearman, P. B., Guisan, A., Broennimann, O., \& Randin, C. F. (2008). Niche dynamics in space and time. Trends in Ecology \& Evolution, 23(3), 149-158. https://doi.org/10.1016/j.tree.2007.11.005

Phillips, S. J., Anderson, R. P., \& Schapire, R. E. (2006). Maximum entropy model- ling of species geographic distributions. Ecological Modelling, 190(3-4), 231-259. https://doi.org/10.1016/j.ecolmodel.2005.03.026

Poglayen-Neuwall, I., Toweill, D. E. (1988). Bassariscus astutus. Mammalian Species, 327,1-8.

Ray, D., Behera, M. D., \& Jacob, J. (2018). Evaluating ecological niche models: A comparison between Maxent and GARP for predicting distribution of Hevea brasiliensis in India. Proceedings of the National Academy of Sciences, India Section B: Biological Sciences, 88, 1337-1343. https://doi.org/10.1007/s40011-017-0869-5

Rodríguez-Estrella, R., Rodríguez-Moreno, A., \& Grajales-Tam, K. (2000). Spring diet of the endemic ring-tailed cat (Bassariscus astutus insulicola) population on an island in the Gulf of California, Mexico. Journal of Arid Environment, 44, 241-246. https://doi.org/10.1006/jare.1999.0579

Sanchez-Pacheco, J. A., Tershy, B., \& Aguilar, J. L. (2000). Acciones de conservación de las islas de México. Gaceta Ecológica. Secretaría de Medio Ambiente y Recursos Naturales. 56, 41-45.

Sansores-Sánchez, R. (2016). Influencia de los Recursos Antropogenicos en la abundancia y dieta de Bassariscus astutus saxicola (Merrian, 1897) en el Complejo Insular Espiritu Santo, Baja California Sur, México. Tesis de Maestria en Ciencias. Centro de Investigaciones Biologicas del Noroeste de México. http://dspace.cibnor.mx:8080/handle/123456789/545

Sappington, J. M., Longshore, K. M., \& Thomson, D. B. (2007). Quantifying Landscape Ruggedness for Animal Habitat Analysis: A case Study Using Bighorn Sheep in the Mojave Desert. Journal of Wildlife Management, 71(5), 1419-1426. https://doi. org/10.2193/2005-723

Toweill, D. E., \& Teer, J. G. (1980). Home range and den habits of Texas ringtails (Bassariscus astutus flavus). In Chapman, J. A., Pursley, D. (Ed.). Proceedings of the Worldwide Furbearer Conference (Maryland). 